Volume 1, Nomor 1, Juli 2018

P-ISSN: 2622-2280 | E-ISSN: 2622-4658

https://ejurnal.iiq.ac.id/index.php/alfanar

\title{
MODERATISME ISLAM DALAM KONTEKS KEINDONESIAAN
}

(Studi Penafsiran Islam Moderat M. Quraish Shihab)

\author{
Iffati Zamimah ${ }^{1}$ \\ Institut Ilmu Al-Qur'an (IIQ) Jakarta \\ Email:ifa@iiq.ac.id
}

\begin{abstract}
Thisstudy proves that Islamicmoderation haslong been known in the Islamictradition. This at once denied the assumption that Islam is a religious that teaching violence. This research is proved by the verses of the Qur'an that have explained the principle of moderate (washatiyah). Through these verses of the Qur'an, Quraish Shihab interprets Islamic moderatism can be applied to the Indonesian context. This study is carried out by exploring the interpretations made by M. Quraish Shihab through Tafsir Al-Mishbah, Wawasan Al-Qur'an, Membumikan Al-Qur'an and others.
\end{abstract}

Keywords: Moderate, Tafsir, Tradition.

\begin{abstract}
Abstrak
Penelitian ini membuktikan bahwa moderasi Islam telah dikenal lama dalam tradisi Islam. Hal ini sekaligus membantah anggapan bahwa Islam merupakan ajaran agama yang mengajarkan kekerasan. Penelitian ini terbukti dengan ayat-ayat AlQur'an yang telah menjelaskan prinsip moderat (washatiyah). Melalui ayat-ayat Al-Qur'an tersebut, Quraish Shibab menafsirkan moderatisme Islam yang dapat diaplikasikan pada konteks Indonesia. Proses ini dilakukan dengan mengeksplorasi penafsiran yang dilakukan oleh M. Quraish Shihab melalui banyak karyanya seperti Tafsir Al-Mishbah, Wawasan Al-Qur'an, Membumikan Al-Qur'an, dan lain-lain."
\end{abstract}

Kata Kunci: Moderat, Tafsir, Tradisi.

\section{PENDAHULUAN}

S aat ini umat Islam menghadapi tantangan internal maupun eksternal. Secara internal, U umat Islam masih berada dalam keterbelakangan pendidikan, ekonomi, dan politik. Sementara pada saat yang sama, secara eksternal, banyak tuduhan dialamatkan kepada Islam, mulai dari tuduhan terorisme, anti-kemajuan, memusuhi wanita, dan sebagainya. ${ }^{2}$

Dari faktor internal, yang dihadapi umat Islam saat ini selain keterbelakangan dalam berbagai sisi, umat Islam juga terkotak menjadi beberapa golongan yang berbeda dalam pemahaman keagamaan; pertama, kecenderungan sebagian kalangan umat Islam yang

1 Dosen Ilmu Al-Qur'an dan Tafsir pada Prodi Komunikasi Penyiaran Islam (KPI) Fakultas Ushuluddin dan Dakwah Institut Ilmu Al-Qur'an (IIQ) Jakarta

2 Muklis M. Hanafi, "Peran Al-Azhar dalam Penguatan Moderasi Islam" Paper pada Seminar Ikatan Alumni Al-Azhar Internasional (IAAI) cabang Indonesia bekerja sama dengan Kedutaan Besar Mesir di Jakarta dan Fakultas Dirasat Islamiyah UIN Syarif Hidayatullah Jakarta. 
bersikap ekstrem dan ketat dalam memahami agama (Islam) serta hukum-hukumnya dan mencoba memaksakan cara tersebut di tengah masyarakat muslim, bahkan dalam beberapa hal dengan menggunakan kekerasan; kedua, kecenderungan lain yang juga ekstrem dengan bersikap longgar dalam beragama dan tunduk pada perilaku serta pemikiran negatif yang berasal dari budaya dan peradaban lain. ${ }^{3} \mathrm{Hal}$ itu disebabkan sebagian umat Islam yang keliru memahami beberapa aspek ajaran Islam, yang akibatnya melahirkan tindakantindakan bertentangan dengan Islam.

Pada sisi lain, tuduhan terhadap Islam juga disebabkan beberapa pihak, khususnya di Barat, yang salah paham terhadap Islam, disamping minimnya pemahaman mereka terhadap substansi ajaran Islam. Dalam konteks inilah, menurut Mukhlis Hanafi pengembangan pemahaman yang benar, toleran, dan moderat menemukan momentumnya. ${ }^{4}$ Intelektual Mesir yang juga alumni Al-Azhar, Dr. Mohammed Ali mengatakan tuduhan-tuduhan miring terhadap Islam tersebut sesungguhnya sama sekali bukan dari ajaran Islam. Islam yang benar adalah Islam yang moderat, dalam pengertian moderat dalam pemahaman keagamaan dan keislaman. ${ }^{5}$

Sikap ekstrem dalam beragama bukanlah fenomena baru dalam sejarah Islam. Sejak periode yang paling dini, sejumlah kelompok keagamaan telah menunjukkan sikap ekstrem ini. Yang paling menonjol adalah kelompok Khawarij, ${ }^{6}$ saat mereka mengkafirkan sebagian umat Islam yang bersebrangan pemahaman dengan mereka.

Di sisi lain muncul pula kelompok yang tak kalah ekstremnya dengan kelompok Khawarij dalam memahami ajaran mereka yaitu Murji'ah, ${ }^{7}$ yang kemunculannya sedikit banyak dipengaruhi oleh sikap ekstrem yang ditunjukkan oleh kelompok Khawarij. Berbeda dengan Khawarij yang frigid (serba tidak boleh), kelompok Murji'ah justru cenderung permisif (serba boleh) terhadap sejumlah ajaran Islam yang sudah jelas ketentuannya. Hampir dalam segala hal, kelompok Murji' ah ini menjadi semacam anti thesis dari kelompok Khawarij. Saat ini sikap seperti Khawarij ini lebih hampir sama dengan pandangan atau

3 Lihat Achmad Satori Ismail, et.al., Islam Moderat: Menebar Islam Rahmatan lil Alamin, (Jakarta: Pustaka Ikadi, 2007), cet. ke-1, h. 13-14.

4 Hanafi, "Peran Al-Azhar dalam Penguatan Moderasi Islam”.

Johnson, "Toleransi Dan Moderasi Inti Ajaran Islam”, www.tribunews.com, diakses 1 April 2013.

Istilah Khawarij dipergunakan untuk menyebut semua kelompok masyarakat yang memberontak terhadap imam yang sah dan telah disepakati oleh mayoritas umat Islam. (Abû al-Fath Muhammad bin Abd al-Karîm asy-Syihristani, al-Milâl wa an-Nihâl, (Syiria: Mu'assah Al-Halabi), Jil. 1, h. 114. Muhammad Khalîl Harras dalam Syarah al-Aqîdah al-Wasathiyyah menjelaskan sejumlah karakteristik mendasar kelompok Khawarij; 1) Mengkafirkan umat Islam yang melakukan dosa besar; 2) Berkeyakinan bahwa iman tidak bertambah dan tidak berkurang namun stagnan; 3) Membolehkan umat Islam untuk memberontak kepada penguasa zalim meskipun tidak menampakkan kekufuran secara nyata; 3) Mengkafirkan setiap individu muslim yang tidak berhukum dengan hukum Allah meskipun dalam sebuah perkara; 4) Tergesa-gesa dalam mengkafirkan setiap individu muslim tanpa menimbang syaratsyaratnya. (lihat Muhammad Khalil Harras, Sharh al-Aqîdah al-Wasathiyyah (t.tp: ar-Ri'âsah al-'Ammah li Idârat al-Buhûth al-'Ilmiyyah wa al-Ifta' wa ad-Da'wah wa al-Irshad, t.th.), cet. 4, h. 267.

Secara bahasa Murji'ah memiliki arti mengakhirkan, takut, angan-angan, memberi, dan mengharap. Sementara itu sebagai sebuah pemahaman teologis, murjiah adalah orang-orang yang berpandangan bahwa iman tidak akan berubah kerena kemaksiatan sebagaimana ketaatan tidak mempengaruhi kekafiran. Lihat ash-Shihristani, al-Milâl wa an-Nihâl, vol. 1, h. 139.

76 | Al-Fanar: Jurnal Ilmu Al-Qur'an dan Tafsir 
sikap radikal, dan sikap seperti Murji'ah berpadaan dengan pandangan atau sikap liberal. ${ }^{8}$ Menurut Khalif Muammar, hal-hal yang bisa membendung liberalisasi agama ini ada tiga hal, yaitu: pertama, pengukuhan worldview Islam dan penguasaan tradisi keilmuan Islam, kedua, menghindari pemikiran dikotomi, dan yang ketiga, adalah pendekatan wasathiyyah. ${ }^{9}$

Selain maraknya dua pemahaman agama yang ekstrem di atas, belakangan ini muncul beberapa konflik bernuansa keagamaan dan ketegangan dalam masyarakat di Indonesia yang dipicu oleh perbedaan pemahaman atau pandangan keagamaan antar kelompok dalam Islam, seperti dihancurkannya basis Ahmadiyyah dan lain-lain. Konflik itu memang tidak berdiri di atas perbedaan pandangan keagamaan semata, tetapi akumulasi dari beberapa persoalan dan kepentingan, baik politik, ekonomi, sosial, dan lainnya. ${ }^{10}$ Namun, terlepas dari ada tidaknya faktor kepentingan, baik yang bersifat internal maupun eksternal, perbedaan pemahaman atau pandangan keagamaan menjadi salah satu penyebab adanya konflik antar kelompok, bisa menjadi penyebab utama atau penyebab perantara. Sebuah perbedaan jika dapat dikelola dengan baik, maka tidak semua akan berujung pada konflik dan kekerasan.

Secara implisit, Al-Qur'an dan Hadis banyak menyinggung akan pentingnya sikap moderat, serta posisi umat Islam sebagai umat yang moderat dan terbaik. Moderasi adalah nilai inti dalam ajaran Islam. Bahkan karakteristik ini dapat menjadi formula untuk mengatasi beragam persoalan umat terkhusus di era globalisasi saat ini seperti persoalan radikalisme keagamaan, takfir, fanatisme buta (at-ta'ashshub al-a'mâ), yang tentunya memerlukan sebuah sikap proporsional dan adil yang teridentifikasikan dalam sebuah konsep yaitu wasathiyyah.

Pada konteks Indonesia saat ini, ada salah satu tokoh yang disebut-sebut sebagai mufasir moderat, yakni M. Quraish Shihab. Melalui banyak karyanya, tokoh mufasir Indonesia ini cukup terkenal sebagai ulama yang mengedepankan persatuan bangsa ditengah pluralitas agama di Indonesia. Shihab memang sempat dicap sebagai tokoh liberal, syiah, dan sebagainya, akan tetapi dia dengan tegas menolak anggapan tersebut. Hal ini terjadi ketika ia telah menulis karya Sunnah Syiah Mungkinkah?. Meski demikian, sebagian kalangan muslim menilai bahwa dia adalah seorang mufasir kontemporer yang moderat dibandingkan dengan mufasir lain di Timur Tengah seperti Sayyid Qutb.

Tafsir al-Mishbah adalah salah satu dari sekian banyak karya Quraish Shihab yang terkait dengan tafsir Al-Qur'an. Sang penulis, M. Quraish Shihab yang saat ini masih hidup dan aktif menulis karya-karya tafsir, dikenal konsen dalam penulisan karya tafsir serta sikapnya yang moderat dalam menyikapi perbedaan yang terjadi ditengah-tengah umat Islam dalam

8 Arus pemikiran ekstrem liberal ini telah melahirkan doktrin-doktrin yang dapat menggerus aqidah umat Islam dan keyakinan mereka yang fundamental. Diantara doktrin tersebut adalah pluralisme dalam beragama dan segala estetikanya. Majelis Ulama Indonesia (MUI) dalam hal ini mengartikan pluralisme agama sebagai sebuah paham yang mengajarkan bahwa semua agama adalah sama dan karenanya kebenaran setiap agama relatif. Oleh sebab itu setiap pemeluk agama tidak boleh mengklaim bahwa hanya agamanyalah yang benar sedangkan yang lain salah. Pluralisme juga mengajarkan bahwa semua pemeluk agama akan masuk surga dan akan hidup berdampingan di dalam surga kelak. Lihat fatwa MUI dalam Musyawarah Nasional (MUNAS) MUI VII, pada 19-22 Jumadil-Akhir 1426 H/26-29 Juli 2005 M, tentang Pluralisme, Liberalisme dan Sekularisme Agama.

9 Khalif Muammar, Atas Nama Kebenaran, Tanggapan Kritis Terhadap Wacana Islam Liberal, (Kuala lumpur: Akademi Kajian Ketamadunan, 2006), h. 292-300.

10 Mukhlis M. Hanafi, Moderasi Islam, (Ciputat: Ikatan Alumni Al-Azhar dan Pusat Studi AlQur'an (PSQ), t.th.), h. 151 
karya-karyanya. Selain tafsirnya yang menggambarkan sikapnya tersebut, dalam tataran kongkrit beliaupun aktif menyebarkan pemahaman moderat melalui lembaga studi yang ia dirikan bersama para koleganya dari para akademisi studi tafsir, PSQ (Pusat Studi Al Qur'an).

Dalam Tafsir Al-Mishbah, Quraish Shihab ketika menafsirkan Surah al-Baqarah ayat 143 menyebutkan bahwa umat Islam dijadikan ummat pertengahan moderat dan teladan, sehingga dengan demikian keberadaan umat Islam adalah dalam posisi pertengahan. Posisi pertengahan menjadikan manusia tidak memihak ke kiri dan ke kanan dan dapat dilihat oleh siapapun dalam penjuru yang berbeda, hal ini mengantarkan manusia berlaku adil dan dapat menjadi teladan bagi semua pihak. Selanjutnya disebutkan bahwa umat Islam akan menjadi saksi atas perbuatan manusia dimana ungkapan "litakûnu” menggunakan fi'il mudhâri' (kata kerja masa datang), hal tersebut mengisyratkan akan adanya pergulatan pandangan dan pertarungan aneka "isme". Namun, pada akhirnya ummatan wasathan inilah yang akan dijadikan rujukan dan saksi tentang kebenaran dan kekeliruan pandangan dan isme-isme itu. ${ }^{11}$

Banyaknya persoalan dalam menemukan sintesa terbaik sebagai umat yang moderat tentu bukan persoalan mudah. Hal ini dikarenakan sikap moderat tidak hanya ditujukan kepada lingkungan internal Islam, akan tetapi juga dengan masyarakat di luar Islam. Melacak gambaran sikap moderat yang diajarkan oleh Islam tentu harus merujuk kepada pegangan utama Islam yakni, Al-Qur'an dan Hadis Nabi Muhammad saw. Pertanyaan yang muncul kemudian adalah bagaimana agar menjadi umat moderat terhadap agama lain?. Tulisan ini agaknya berupaya menggambarkan Islam moderat yang dijelaskan melalui dalil-dalil normatif melalui penafsiran para ulama modern Indonesia.

\section{QURAISH SHIHAB DALAM KONTEKS KEINDONESIAAN.}

Quraish Shihab adalah pengarang kitab Tafsir Al-Mishbah. Ia bernama lengkap Muhammad Quraish Shihab seorang putra kelima dari dua belas bersaudara, lahir di Rappang Sulawesi Selatan pada tanggal 16 Februari 1944. ${ }^{12}$ Ia berasal dari keturunan Arab terpelajar. Ayahnya, Abdurrahman Shihab (1905-1986) adalah seorang ulama tafsir dan guru besar dalam bidang ilmu tafsir di IAIN Makasar. Beliau adalah alumni Jami'at al-Khair Jakarta. ${ }^{13}$ Di samping sebagai wiraswasta, Abdurrahman Shihab sudah aktif mengajar dan berdakwah sejak muda. Di tengah kesibukannya ia masih selalu menyempatkan diri dan meluangkan waktu, pagi dan petang untuk membaca Al-Qur'an dan kitab tafsir. ${ }^{14}$

Abdurrahman Shihab adalah guru besar dalam bidang tafsir yang pernah menjabat

11 M. Quraish Shihab, Tafsir Al-Mishbah, (Ciputat: Lentera Hati, 2000), cet. I ,vol. I, h. 325.

12 M.Quraish Shihab, Membumikan Al-Quran: Fungsi dan Peran Wahyu dalam Kehidupan Masyarakat, (Bandung: Mizan, 2007), h. 14.

13 Jâmi'at al-Khayr adalah sebuah lembaga pendidikan Islam tertua di Indonesia yang ikut meletakkan fondasi modernisme Islam di Indonesia. Jalinan kerjasama lembaga pendidikan ini dengan pusat-pusat keilmuwan Islam di Timur Tengah, baik Hadramaut, Haramain maupun Kairo, membawa Jâmi'at al-Khair pada posisi penting dalam gerakan Islam di Indonesia. Lembaga inilah yang mengundang guru-guru dari kawasan Timur Tengah untuk mengajar. Diantaranya adalah Ahmad Syurkati, ulama asal Sudan Afrika Utara. Syurkati dikenal sebagai salah seorang pendiri Al-Irsyad, sebuah organisasi sosial keagamaan yang memiliki pengaruh kuat dikalangan keturunan Arab di Indonesia. (Lihat Arief Subhan, Tafsir Yang Membumi, (Jakarta: Majalah Tsafaqah, 2003), vol. 1, no.3, h.82.

14 M. Quraish Shihab, Membumikan Al-Quran 2, (Ciputat: Lentera Hati, 2011), h. 14. 
sebagai rektor IAIN Alaudin Makasar, perguruan tinggi Islam yang mendorong tumbuhnya Islam moderat di Indonesia. Beliau juga salah seorang penggagas berdirinya UMI (Universitas Muslim Makasar) yaitu universitas Islam swasta terkemuka di Makasar. Muhammad Quraish Shihab sendiri mengaku bahwa dorongan untuk memperdalam studi Al-Qur'an terutama tafsir datang dari ayahnya. Ayahnya senantiasa menjadi motivator bagi Muhammad Quraish Shihab untuk melanjutkan pendidikannya lebih lanjut. ${ }^{15}$

Ketertarikannya terhadap tafsir Al-Qur'an sangat beralasan. Semenjak kecil ia didik dengan Al-Qur'an, karena Ayahnya adalah pakar Al-Qur'an dan tafsir. Quraish kecil telah menjalani pergumulan dan kecintaan terhadap Al-Qur'an sejak umur 6-7 tahun. Ia harus mengikuti pengajian Al-Qur'an yang diadakan oleh ayahnya sendiri. Selain menyuruh membaca Al-Qur'an, ayahnya juga menguraikan secara sepintas kisah-kisah dalam AlQur'an. Di sinilah, benih-benih kecintaannya kepada Al-Qur'an mulai tumbuh.

Pendidikan Quraish Shihab dimulai dari kampung halamannya sendiri. Ia menempuh pendidikan dasar di kotanya kelahirannya, Ujung Pandang. Selanjutnya ia melanjutkan pendidikan menengahnya di Malang, sambil mengaji di Pondok Pesantren Darul Hadis al-Fiqhiyyah. Pada tahun 1958, ketika usianya 14 tahun dia berangkat ke Kairo Mesir dan diterima di kelas II Tsanawiyah al-Azhar dan pada tahun 1967 dia meraih gelar Lc (S.1) pada fakultas Ushuluddin jurusan Tafsir Hadis Universitas al-Azhar. Kemudian pada tahun 1969 meraih gelar M.A dari fakultas yang sama untuk spesialisasi bidang Tafsir Al-Qur'an dengan tesis al-I'Jâz at-Tasyrìî lî Al-Qur'an al Karîm. ${ }^{16}$

Sekembalinya ke Ujung Pandang, Quraish Shihab dipercayakan untuk menjabat Wakil Rektor bidang Akademis dan Kemahasiswaan pada IAIN Alauddin, Ujung Pandang. Selain itu, dia juga diserahi jabatan-jabatan lain, baik di dalam kampus, seperti Koordinator Perguruan Tinggi Swasta (Wilayah VII Indonesia Bagian Timur), maupun di luar kampus, seperti Pembantu Pimpinan Kepolisian Indonesia Timur dalam bidang pembinaan mental. Selama di Ujung Pandang ini, dia juga sempat melakukan berbagai penelitian, antara lain: penelitian dengan tema "Penerapan Kerukunan Hidup Beragama di Indonesia Timur"(1975) dan "Masalah Wakaf Sulawesi Selatan" (1978).

Meskipun sudah menduduki sejumlah jabatan di Indonesia, semangat Muhammad Quraish Shihab untuk melanjutkan pendidikannya, karena ayahnya selalu berpesan agar anaknya berhasil mencapai gelar doktor tidaklah pudar. Oleh karena itu ketika ada kesempatan untuk melanjutkan studi, tepatnya pada tahun 1980, Muhammad Quraish Shihab kembali ke Kairo dan melanjutkan pendidikannya di almamaternya yang lama, Universitas Al Azhar pada tahun 1982, dengan disertasi berjudul "Nazhm ad-Durâr li alBiqa’̂̀: Tahqîq wa Dirâsah". Beliau berhasil meraih gelar doktor dalam ilmu-ilmu Al-Qur'an dengan nilai yudisium summa cumlaude, disertasi dengan penghargaan tingkat I (mumtâz ma'a martabat al-syaraf al-îla). ${ }^{17}$

Dengan demikian, secara keseluruhan M. Quraish Shihab telah menjalani pengembangan intelektualnya di bawah asuhan dan bimbingan al-Azhar (termasuk studinya pada tingkat Tsanawiyah dan 'Aliyah) selama sekitar 13 tahun. Hampir dapat dipastikan bahwa iklim dan tradisi keilmuan dalam studi Islam di lingkungan Universitas al-Azhar memiliki pengaruh-pengaruh tertentu terhadap kecenderungan intelektual dan corak pemikiran keagamaan beliau.

\footnotetext{
15 Subhan, Tafsir yang Membumi, h. 82.

16 QuraishShihab, Membumikan Al-Qur'an, h. 6.

17 Subhan, Tafsir Yang Membumi, h. 6.
} 
Setelah meraih gelar doktor dalam bidang ilmu-ilmu Al-Qur'an, M. Quraish Shihab kembali ke tempat tugas semula, IAIN Alaudin Ujung Pandang. Tidak sampai dua tahun, pada tahun 1984 dia hijrah ke Jakarta dan ditugaskan pada Fakultas Ushuluddin dan Fakultas Pascasarjana IAIN Syarif Hidayatullah Jakarta. ${ }^{18}$ Di luar kampus, dia juga dipercaya menduduki sejumlah jabatan penting, antara lain Ketua Majelis Ulama Indonesia (MUI) Pusat sejak 1984, Anggota Lajnah Pentashih Al-Qur'an Departemen Agama sejak 1989, dan Anggota Badan Pertimbangan Pendidikan Nasional sejak 1989. Dalam kabinet Pembangunan VII yang dilantik bulan Maret 1998, M. Quraish Shihab duduk sebagai Menteri Agama. Namun, kabinet tersebut hanya berusia dua bulan dan jatuh pada tanggal 2 Mei 1998. Kemudian pada tahun 1999, beliau diangkat sebagai Duta Besar Luar Biasa dan Berkuasa penuh untuk Mesir. Pada saat inilah M. Quraish Shihab memulai menulis karya monumentalnya Tafsir al Mishbah.

Quraish Shihab juga aktif dalam kegiatan tulis menulis. Di surat kabar Pelita, Pada setiap hari Rabu dia menulis dalam rubrik "Pelita Hati". Dia juga mengasuh rubrik Tafsir al-Amanah dalam majalah dua mingguan yang terbit di Jakarta. Selain itu dia juga tercatat sebagai anggota Dewan Redaksi Majalah Ulumul Qur'an dan Mimbar Ulama, keduanya terbit di Jakarta. Pada tahun 2004, M. Quraish Shihab mendirikan lembaga kajian AlQur'an yang diberi nama Pusat Studi Al-Qur'an (PSQ). Diantara karya-karya M.Quraish Shihab adalah: Filsafat Hukum Islam, Mahkota Tuntunan Ilahi (Tafsir Surah al-Fatihah), Membumikan Al-Qur'an 1 dan 2, Jilbab Pakaian Wanita Muslimah, Untaian Permata Untuk Anakku, Wawasan Al-Qur'an, Mukjizat Al-Qur'an, Menyingkap Tabir Ilahi, FatwaFatwa Seputar Ibadah dan Muamalah, Tafsir Al-Mishbah dan masih banyak yang lainnya.

Menurut Howard M. Federspiel, dengan mengacu kepada buku Membumikan Al Qur'an, Lentera Hati, dan Wawasan Al-Qur'an, menunjukkan bahwa seting sosial karyakarya M. Quraish Shihab mencakup masyarakat awam dan kaum terpelajar; dalam bahasa Federspiel sendiri dikatakan "ia ditulis untuk dapat digunakan oleh kaum muslim awam, tetapi sebenarnya ia ditujukan kepada pembaca yang cukup terpelajar". ${ }^{19}$

M. Quraish Shihab memang bukan satu-satunya pakar Al-Qur'an (pakar tafsir) di Indonesia, tapi kemampuannya menterjemahkan dan menyampaikan pesan-pesan AlQur'an dalam konteks masa kini dan masa modern membuatnya lebih dikenal dan lebih unggul dari pada pakar Al-Qur'an lainnya.

\section{AKAR MODERATISME ISLAM}

Pemahaman paling mendasar dalam mengenal Moderatisme yang diajarkan oleh Islam tergambar dari penjelasan yang terdapat di dalam Al-Qur'an. Al-Qur'an pada umumnya menggunakan istilah 'al-Wasathiyyah' untuk mengungkap makna moderat dalam Islam. Walaupun sebenarnya terdapat perbedaan-perbedaan dengan pemahaman moderat dalam konteks saat ini. Oleh sebab itu pemahaman dasar ini bisa dijadikan akar dalam memahami moderatisme Islam sebenarnya.

Kata 'al-wasathiyyah' berakar pada kata al-wasth (dengan huruf sin yang di-sukûn-kan) dan al-wasath (dengan huruf sin yang di-fathah-kan) yang keduanya merupakan mashdâr (infinitife) dari kata kerja (verb) wasatha. Secara sederhana, pengertian Wasathiyyah

18 Mustafa, M. Quraish Shihab Membumikan Kalam di Indonesia, (Yogyakarta: Pustaka Pelajar, 2010), cet. 1 , h 72 .

19 Howard M. Federspiel, Kajian Al-Qur'an Indonesia: Dari Mahmud Yunus Hingga Quraish Shihab, terj. Tajul Arifin, (Bandung: Mizan, 1996), h. 298.

80 | Al-Fanar: Jurnal Ilmu Al-Qur'an dan Tafsir 
secara terminologis berangkat dari makna-makna etimologis di atas yang artinya suatu karakteristik terpuji yang menjaga seseorang dari kecendrungan bersikap ekstrim.

Adapun kata al-wasth merupakan pola zharf yang berarti baina (diantara). Sedangkan kata al-wasathu, mengandung empat pengertian, yaitu: pertama, kata benda (ism) yang bermakna posisi pertengahan diantara dua posisi bersebrangan. Kedua, sebagai kata sifat yang berarti pilihan (khiyâr), utama (afdhal), dan terbaik (ajwad). Ketiga, mengandung arti 'adl (adil). Keempat, mengandung arti sesuatu yang berada diantara hal yang baik dan hal yang buruk/netral (asy-syay'u baina al-jayyid wa ar-rad ${ }^{\wedge} i$ ).

Adapun jika kedua kata di atas diderivasikan, maka pengertiannya akan berkisar pada pengertian adil, utama, pilihan/terbaik, dan seimbang antara dua posisi yang berseberangan. Diantaranya, kata wasith yang berarti hasî̀b dan sharîf, seperti perkataan Jauhari: "fulân wasith fî qaumihi idzâ kâna ausathuhum nasaban wa arfa'uhum mahallan." Dan kata alwasath yang berarti al-mutawassith baina al-mutakhassimaini (penengah antara dua orang yang berselisih). Demikian pula derivasi-derivasi lainnya, seperti: at-tawassuth, at-tausith, dan wâsithah. ${ }^{20}$

Berangkat dari pengertian-pengertian dasar wasathiyyah dalam kamus-kamus bahasa Arab, dapat disimpulkan bahwa konsep wasathiyyah secara etimologi memiliki dua pengertian besar yaitu: pertama, sebagai kata benda (ism) dengan pola zharf yang lebih bersifat kongkrit (hissî), yaitu sebagai perantara atau penghubung (interfacelal-bainiyyah) antara dua hal atau dua kondisi atau antara dua sisi berseberangan. Kedua, lebih bersifat abstrak (theoretical) yang berarti terbaik, adil, pilihan, dan utama (superiority/al-khiyâr). ${ }^{21}$ Raghib al-Ashfahani (w. $502 \mathrm{H}$ ) mengartikannya sebagai titik tengah, seimbang tidak terlalu ke kanan (ifrâth) dan tidak terlalu ke kiri ( $t a f r i t h)$, di dalamnya terkandung makna keadilan (al-'adl), kemulian, dan persamaan (al-musawah). ${ }^{22}$

Dalam buku Strategi al-wasathiyyah yang dikeluarkan oleh Kementerian Wakaf dan Urusan Agama Islam Kuwait dan dikutip oleh Mukhlis Hanafi, wasathiyyah didefinisikan sebagai sebuah metode berpikir, berinteraksi, dan berperilaku yang didasari atas sikap tawâzun (seimbang) dalam menyikapi dua keadaan perilaku yang dimungkinkan untuk dianalisis dan dibandingkan, sehingga dapat ditemukan sikap yang sesuai dengan kondisi dan tidak bertentangan dengan prinsip-prinsip ajaran agama dan tradisi masyarakat. ${ }^{23}$ Dengan pengertian ini sikap wasat\}iyyah akan melindungi seseorang dari kecenderungan terjerumus pada sikap berlebihan.

20 Lihat Ali Muhammad Muhammad ash-Shalabî, al-Wasathiyyah fî Al-Qur'ân, (Kairo: Maktabat at Tâbi'in, 1422/2001), cet. ke-1, h. 13-15. Dikutip dari kamus-kamus berikut: Abu al Husain Ahmad Ibn Faris, Mu'jam Maqâyis al-Lughagh, (t.tp: Dâr al-Fikr, 1399/1979), jilid. VI, h. 108. Lihat juga Ibn Manzhur, Lisân al-'Arab, (Beirut: Dar ash-Shadîr, t.th), cet. ke-1, jilid. VII, h. 427-431. Lihat

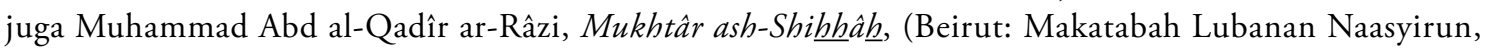
1415/1995), jilid. I, h. 740. Lihat juga Majd ad-Dîn al-Fairuz Abadi, al-Qâmûs al-Muhîth, (t.tp: Mu'assasah ar Risalah, t.th), h. 893. Lihat juga Ahmad bin Muhammad al Muqri al Fayumi, al-Mishbâh al-Munîr fî Garîb asy-Syarh al-Kabîr (Beirut: al Maktabah al Ilmiah, t.th), jilid. II, h. 658.

21 Lihat Ali Muhammad Muhammad al-Shalabi, Al-Wasathiyyah fî Al-Qur'an, h. 14.

22 Raghib al-Ashfahani, Mufradât Alfâzh Al-Qur'an (Damaskus: Dâr al-Qalam, t.th), jilid. II, h. 513.

23 Dikutip dan diterjemahkan dari dokumen yang diterbitkan pemerintah Kuwait sebagai strategi untuk mensosialisasikan konsep al-Wasathiyyah melalui pemahaman yang toleran dan moderat. Lihat Mukhlis M. Hanafi, "Konsep al-Wasathiyyah Dalam Islam”, Harmoni: Jurnal Multikultural dan Multireligius, Vol. VIII, (Oktober-Desember, 2009), h. 40. 


\section{MODERATISME ISLAM DALAM KONTEKS KEINDONESIAAN}

(Studi Penafsiran Islam Moderat M. Quraish Shihab)

Yusuf Al-Qardhawi menjelaskan, wasathiyyah yang dapat disebut juga dengan at-tawâzun, yaitu upaya menjaga keseimbangan antara dua sisi/ujung/pinggir yang berlawanan atau bertolak-belakang, agar jangan sampai yang satu mendominasi dan menegaskan yang lain. Sebagai contoh dua sisi yang bertolak belakang; spiritualisme dan materialisme, individualisme, dan sosialisme, paham yang realistik dan yang idealis, dan lain sebagainya. Bersikap seimbang dalam menyikapinya yaitu dengan memberi porsi yang adil dan proporsional kepada masing-masing sisi/pihak tanpa berlebihan, baik karena terlalu banyak maupun terlalu sedikit. ${ }^{24}$

Adapun pengertian wasathiyyah menurut terminologi Islam, ${ }^{25}$ yang bersandarkan kepada sumber-sumber otoritatifnya, secara terperinci Al-Qardhawi mendefinisikannya sebagai sebuah sikap yang mengandung pengertian keadilan sebagai konsekuensi diterimanya kesaksian seorang saksi berdasarkan QS. al-Baqarah [2]: 143. Berarti juga konsistensi dalam manhaj (istiqâmah al-manhaj) dan jauh dari penyelewengan dan penyimpangan berdasarkan QS. al-Fâtihah [1]: 6. Berarti pula dasar kebaikan (dalîl alkhairiyyah) dan penampakan keutamaan dan keistimewaan dalam perkara kebendaan (almâddiyyât) dan kemaknawian (al-ma'nawiyyât). Juga berarti tempat yang penuh keamanan yang jauh dari marabahaya. Demikian pula berarti sumber kekuatan dan pusat persatuan dan perpaduan. ${ }^{26}$

Seseorang yang adil akan berada di tengah dan menjaga keseimbangan dalam menghadapi dua keadaan. Bagian tengah dari kedua ujung sesuatu dalam bahasa Arab disebut wasath. Kata ini mengandung makna baik, seperti dalam sebuah hadis, "Sebaik-

24 Al-Qaradhawi, al-Khashâish al-'Ammah li al-Islâm, h. 127.

25 Pembatasan pengertian wasathiyyah pada konsepsi Islam berangkat dari suatu fakta bahwa konsep ini merupakan murni dan orisinil sebuah konsep yang berasal dari Islam dengan segala kandungannya sebagaimana yang ditegaskan Al-Qardhawi. Namun jika konsep ini disepadankan dengan konsep moderasi yang berkembang, maka dalam konteks ini, menurut penulis, setidaknya terdapat dua terminologi yang harus dibedakan, hingga tidak menimbulkan kerancuan persepsi tentang Islam itu sendiri, yaitu, "Islam Moderat" dan "Moderasi Islam". Untuk terminologi pertama, pada dasarnya term ini tidak pernah dikenal dalam Islam, karena Islam sebagai agama yang telah sempurna, lengkap, dan satu (QS. al-Mâidah [5]: 3, QS. al-Anbiyâ’ [21]: 92, QS. al-Mu'minûn [23]: 52) tidak mengenal kategorisasi apapun dalam hakikatnya. Apakah itu kategorisasi yang lebih bersifat negatif, seperti Islam radikal, Islam fundamentalis, Islam militan, Islam jihadis, dan lainnya. Maupun kategorisasi yang lebih dianggap bersifat positif seperti Islam progresif, Islam moderat, Islam modernis dan lainnya. Adapun untuk terminologi kedua, umat Islam sepanjang masa telah sepakat bahwa moderasi sebagai padanan kata wasathiyyah merupakan salah satu karakteristik maupun cara berfikir yang telah melekat dalam Islam itu sendiri merujuk sumber-sumbernya yang otoritatif. Sedangkan sikap-sikap ekstrimis yang terjadi dalam diri umat Islam, merupakan bagian dari penyimpangan yang harus diluruskan. Sebagaimana yang terjadi pada sekte khawârij pada masa Sahabat ridhwanullah 'alaihim. Maupun sekte qadariyyah dan jabariyyah pada masa-masa berikutnya. Selain itu, tetap harus dibedakan pula Islam sebagai agama dan ajaran, dengan pemeluknya. Sebagai agama dan ajaran, Islam tidak pernah beruba hal. Islam sudah lengkap dan sempurna. Hanya saja, pemahaman pemeluknya terhadap Islam itulah yang berbeda-beda; ada yang lengkap dan tidak; ada yang memahami Islam dari satu aspek, sementara aspek yang lain ditinggalkan, misalnya, Islam hanya dipahami dengan tasâmuh (toleransi)-nya saja, sementara ajaran Islam yang lain, yang justru melarang tasâmuh tidak dipakai. Dari sini, seolah-olah Islam hanya mengajarkan tasâmuh sehingga Islam terkesan permisif. Padahal kenyataannya ada yang boleh ditoleransi, dan ada pula yang tidak. Jadi, tetap harus dipilah antara Islam dan orangnya.

26 Al-Qardhawi, Al-Khashâish al-Âmmah li al-Islâm, h. 131-134. 
sebaik urusan adalah awsathuhâ (yang pertengahan)", ${ }^{27}$ karena yang berada di tengah akan terlindungi dari cela atau aib yang biasanya mengenai bagian ujung atau pinggir. Kebanyakan sifat-sifat baik adalah pertengahan antara dua sifat buruk, seperti sifat berani yang menengahi antara takut dan sembrono, dermawan yang menengahi antara kikir dan boros, dan lainnya.

Pandangan ini dikuatkan pula oleh ungkapan Aristoteles yang mengatakan, "Sifat keutamaan adalah pertengahan diantara dua sifat tercela". ${ }^{28}$ Begitu melekatnya kata wasath dengan kebaikan sehingga pelaku kebaikan itu sendiri dinamai juga wasathdengan pengertian orang yang baik. Karena itu ia selalu adil dalam memberi keputusan dan kesaksian. ${ }^{29}$ Dari kata ini pula lahir kata wasith dalam bahasa Indonesia yang bermakna; pertama, penengah; perantara (dagang dsb); kedua, penentu; pemimpin (dalam pertandingan sepakbola, bola, voli, dsb); ketiga, pemisah; pelerai (antara yang berselisih dsb). ${ }^{30}$

Dalam Al-Qur'an term wasatha disebut 5 kali, yaitu:

1. صَارَ فِي الوَسْطِ (Berpindah ke tengah barisan), yaitu merangseknya pasukan berkuda ketengah-tengah medan perang untuk memporak-porandakan barisan musuh; menggunakan kata wasth. Makna ini terkandung dalam surah al-Âdiyât [100]: 5

2. أعدل وأعقل (lebih adil dan lebih berakal); menggunakan kata awsathuhum dan wustha. Makna ini terkandung dalam surah al-Qalam [68]: 28 dan al-Baqarah [2]: 238

3. Lebih dekat dengan kepantasan antara boros dan bakhil; menggunakan kata awsath. Makna ini terkandung dalam surah al-Mâidah [5]: 89

4. Sebagai sifat yang menunjukkan keutamaan dan keadilan; menggunakan kata ummatan Wasathan. Makna ini terkandung dalam surah al-Baqarah [2]: 143

Selain itu kata wasathiyyah juga seringkali disinonimkan dengan kata 'al-iqtishâd' dengan pola subjeknya, 'al-muqtashîd Namun, secara aplikatif kata wasathiyyah lebih populer digunakan untuk menunjukkan sebuah paradigma berfikir paripurna, khususnya yang berkaitan dengan sikap beragama dalam Islam. ${ }^{31}$ Hal ini didasarkan pada banyaknya karya tulis yang berbicara tentang karakteristik Islam pada aspek wasathiyyah dengan menggunakan term wasathiyyah itu sendiri sebagai istilah baku dalam kajian tersebut. ${ }^{32}$

27 Lihat Abu Bakr Abdullah bin Ibn Abi Syaibah, Mushannaf Ibn Abî-Syaibah, (t.tp.: Dâr al-Qiblah dan Dâr as-Salafiyah al-Hindiah al-Qadîmah, t.th), jilid. XIII, h. 479, No. hadis 36276. Lihat juga Ahmad bin al-Husain Abu Bakr al-Baihaqi, Syu'ab al-Iman, (Riyadh: Maktabah ar-Rushd, 1423/2003), jilid. V, h. 261, jilid. III, h. 402, jilid. V, h. 261, jilid. VIII, h. 518 dari Sahabat Mutharrif bin Abdillah, Ali, dan Ibn Abbas, no. Hadis 6176, 3888, 6601, 6176,

28 Yusuf Al-Qaradhawi, al-Khashâish al-'Ammah li al-Islâm, (Beirut: Mu'assasah ar-Risalah, 1404/1983), cet. ke-2, h. 133.

29 Muhammad Ali an-Najjar, Mu'jam Alfâzh Al-Qur'an al-Karîm, (Kairo: Majma' al-Lughagh al'Arabiyyah, 1996), jilid. VI, h. 248.

30 Tim Penyusun Kamus Pusat Bahasa, Kamus Besar Bahasa Indonesia, (Jakarta: Balai Pustaka, 2005), cet. ke- 3, h. 1270.

31 Lihat Muhammad az-Zuhailî, Indahnya Islam: Di tengah Tarikan Kaum Ekstrim dan Liberal, terj. Kuwais dan Ahmad Yunus Naidi, (Jakarta: Akbar Media Eka Sarana, 1492/2008), cet. ke- I, h. 191. Lihat juga Muhammad Ali asy-Syaukani, Fath al-Qadîr: al-Jâmi' Bayna Fannayi ar-Riwâyah wa adDirâyah min 'Ilm at-Tafsîr, (Riyadh: Maktabah ar-Rushd, 1428 H/2007 M), cet. ke-5, jilid. II, h. 97.

32 Semisal karya-karya tulis berikut: al-Wasathiyyah fi Al-Qur'an karya Ali Muhammad asy Syalabi, Wasathiyyah Ahl as-Sunnah baina al-Firâq karya Muhammad Bakarim Muhamad Baabdullah, al-Islâm Dîn al-Wasathiyyah wa al-Fadhîil wa al-Qiyâm al-Khâlidah karya Abd as-Salam al Harras. 


\section{MODERATISME ISLAM DALAM KONTEKS KEINDONESIAAN}

(Studi Penafsiran Islam Moderat M. Quraish Shihab)

Sementara itu dalam perkembangannya kata wasathiyyah seringkali disepadankan pula dengan istilah 'Moderasi' yang secara etimologi berasal dari bahasa Inggris 'moderation' artinya sikap sedang, tidak berlebih-lebihan. Adapun 'Moderator' adalah seorang penengah, atau pelerai. ${ }^{33}$

\section{PENAFSIRAN MODERATISME ISLAM DAN KONTEKSTUALISASINYA}

Banyak dalil-dalil Al-Qur'an yang merujuk pada pemahaman seputar moderatisme Islam. Beberapa sampel dalil itu setidaknya dipaparkan sebagai berikut:

\section{QS. Al-'Adiyat [100]: 5}

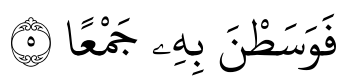

"Dan menyerbu ke tengah-tengah kumpulan musuh" (QS. al-'Adiyat [100]: 5).

Quraish Shihab menjelaskan secara umum bahwa kehadiran hari kiamat, datang tanpa disangka. Kehadirannya seperti serangan yang datang dengan tiba-tiba dari tentara berkuda di tengah kelompok yang merasa dirinya kuat tetapi ternyata diporakporandakan. ${ }^{34}$

Quraish Shihab dalam tafsirnya mengatakan bahwa awsathubum dalam ayat ini bermakna saudara mereka yang di tengah, yakni yang paling moderat dan baik pikirannya diantara mereka. Mereka berkata: "Bukankah aku telah mengatakan kepada kamu, bahwa rencana kamu itu tidaklah terpuji dan bahwa hendaklah atau mengapa kamu tidak senantiasa bertasbih menyucikan Allah dan berucap InsyaAllah?!” Rupanya ketika itu juga para pemilik kebun tersebut sadar, karena itu mereka berucap: Maha Suci Tuhan Pemelihara kita, sesungguhnya kita tadinya dengan rencana buruk kita adalah orang-orang zalim yang mantap kezalimannya sehingga menempatkan sesuatu bukan pada tempatnya. Mestinya kita bersyukur dengan hasil panen sambil memberi hak fakir dan miskin, tetapi justru kita melakukan sebaliknya. ${ }^{35}$

QS. Al-Maidah [5]: 89

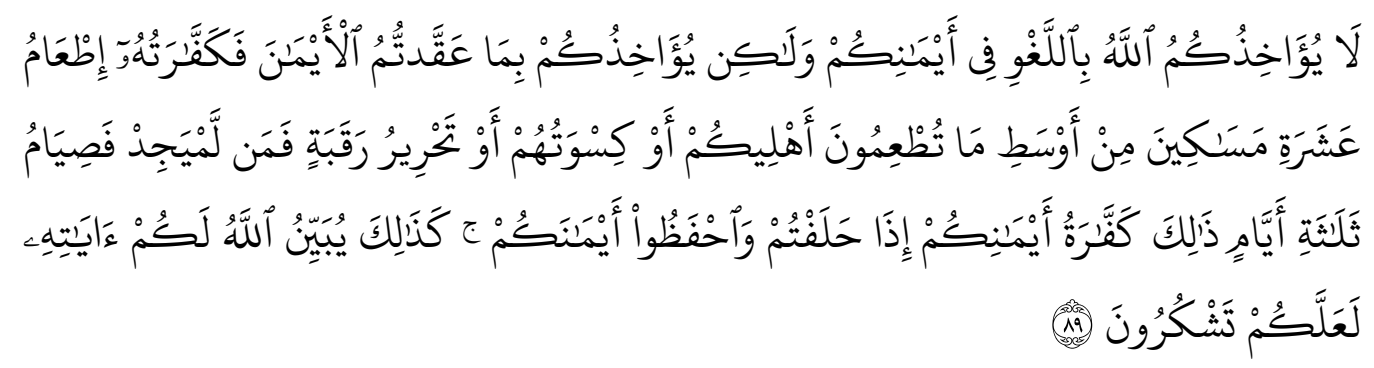

"Allah tidak menghukum kamu disebabkan sumpah-sumpahmu yang tidak dimaksud (untuk bersumpah), tetapi Dia menghukum kamu disebabkan sumpah-sumpah yang kamu sengaja, Maka kaffarat (melanggar) sumpah itu, ialah memberi Makan sepuluh orang miskin, Yaitu dari makanan yang biasa kamu berikan kepada keluargamu, atau memberi pakaian kepada mereka atau memerdekakan seorang budak. barang siapa tidak sanggup melakukan yang demikian, Maka kaffaratnya puasa selama tiga hari.

33 John M. Echols dan Hasan Shadily, An English-Indonesiam Dictionary, (Jakarta: PT. Gramedia Pustaka Utama, 2005), cet. ke-26, h. 384. Lihat juga Abdurahman M. Abdullah (Baadiyow), The Islah Movement:Islamic Moderation in War-torn Somalia, (Mogadishu: t.p., 2008), h. 3.

34 Quraish Shihab, Tafsîr Al-Mishbah, vol. 15, h. 464.

35 Quraish Shihab, Tafsîr Al-Mishbah, vol. 14, h. 390.

84 | Al-Fanar: Jurnal Ilmu Al-Qur'an dan Tafsir 
yang demikian itu adalah kaffarat sumpah-sumpahmu bila kamu bersumpah (dan kamu langgar). dan jagalah sumpahmu. Demikianlah Allah menerangkan kepadamu bukum-bukum-Nya agar kamu bersyukur (kepada-Nya)" (QS. al-Maidah [5]: 89).

Konteks ayat ini berbicara tentang kafarat (denda pelanggaran) bagi orang yang melanggar sumpah dengan disengaja. Kafaratnya yaitu pertama, memberi makanan kepada sepuluh orang miskin yang diberikan satu kali. Masing-masing dari mereka menerima makanan yang biasa dimakan keluarga di rumah. Bukan makanan-makanan yang paling rendah yang biasa dimakan dalam keadaan hidup susah, bukan pula makanan paling tinggi yang mereka makan ketika hidup lapang seperti makanan hari raya dan lain-lain yang biasa disuguhkan kepada para tamu. Makna wasath di sini adalah bermakna ukuran untuk makanan yang layak dan pantas dan pertengahan. ${ }^{36}$

Kata awsath atau pertengahan dalam arti makanan yang biasa dimakan, bukan hidangan istimewa. Ada juga yang memahaminya dalam arti yang terbaik. Memang kata tersebut dapat diartikan demikian, tetapi pendapat pertama lebih kuat, apalagi salah satu ciri agama Islam adalah moderasi, bahkan kebajikan adalah pertengahan antara dua ekstrim. Seperti kedermawanan adalah pertengahan antara sifat kikir dan boros; keberanian adalah pertengahan antara takut dan ceroboh. ${ }^{37}$

Quraish Shihab menjelaskan Arti kalimat as-shalat al-wustha adalah shalat pertengahan. Pertengahan tersebut ada yang memahaminya dalam arti pada bilangan rakaatnya, yaitu shalat Maghrib, karena rakaatnya yang tiga adalah pertengahan antara shalat Ashar, Isya (empat rakaat) dengan subuh yang dua rakaat. Ada juga yang memahami pertengahan dari segi masa pertama shalat diwajibkan. Menurut riwayat, shalat Zhuhur adalah yang pertama, disusul Ashar kemudian Maghrib, Isya, dan Subuh, kalau demikian yang jadi pertengahan adalah shalat Maghrib. ${ }^{38}$

Kalau pertengahan diukur dari ukuran hati, maka ukuran hati dalam pandangan Islam dimulai dengan terbenamnya matahari, yakni Maghrib. Jika demikian yang pertengahan adalah Subuh. Ada juga yang menjadikan tolak ukurnya dari segi bacaan yang dikeraskan dan dirahasiakan, Ada juga yang memahaminya berdasar perintah memelihara, dalam arti memberi kesan bahwa yang dipelihara adalah yang mengandung kemungkinan diabaikan, dan yang demikian itu biasanya yang berat. Maka penganut tolak ukur ini menetapkan shalat $a l$-Wusthâ atas dasar shalat yang paling berat. Di sini tentu muncul lagi perbedaan tentang shalat yang paling berat. Masih banyak pendapat lain yang keseluruhannya melebihi dua puluh pendapat. ${ }^{39}$

\section{QS. Al-Baqarah [2]: 142-143.}

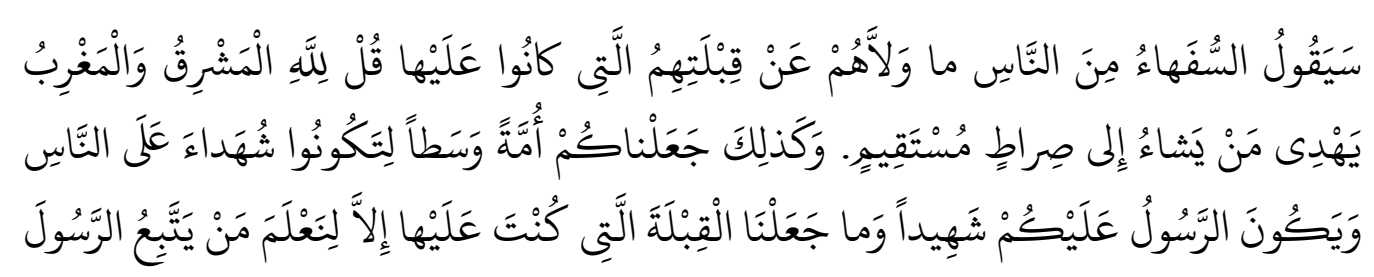

\footnotetext{
36 Al Marâghî, Tafsîr al-Marâghî, juz VII, h. 21-22

37 Quraish Shihab, Tafsir Al-Mishbah, vol.3, h. 190

38 Quraish Shihab, Tafsir Al-Mishbah, vol. 1, h. 519

39 Quraish Shihab, Tafsir Al-Mishbah, vol. 1, h. 520
} 


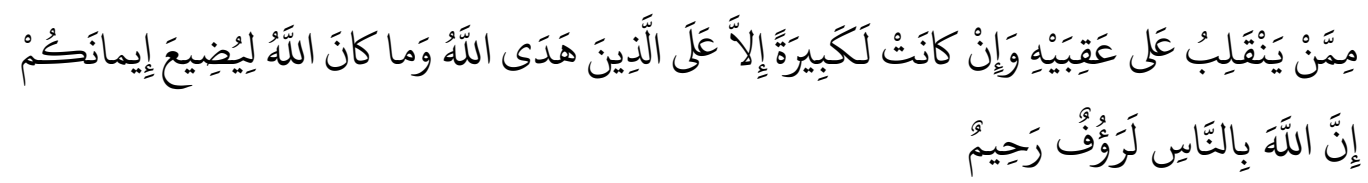

"Dan demikian (pula) Kami telah menjadikan kalian (umat Islam), umat yang Wasath (adil dan pilihan) agar kalian menjadi saksi atas (perbuatan) manusia dan agar Rasul (Muhammad) menjadi saksi atas (perbuatan) kalian. Dan Kami tidak menetapkan kiblat yang menjadi kiblatmu (sekarang) melainkan agar Kami mengetahui (supaya nyata) siapa yang mengikuti Rasul dan siapa yang membelot. dan sungguh (pemindahan kiblat) itu terasa amat berat, kecuali bagi orang-orang yang telah diberi petunjuk oleh Allah; dan Allah tidak akan menyia-nyiakan imanmu. Sesungguhnya Allah Maha Pengasih lagi Maha Penyayang kepada manusia" (QS. al-Baqarah [2]: 142-143).

Sebagaimana para mufassir kontemporer lainnya, Quraish Shihab termasuk diantara ulama tafsir yang konsisten mendasarkan dan menyeru kepada prinsip wasathiyyah sebagai sebuah karakter dan metode memahami nash Al-Qur'an. ${ }^{40}$ Secara bahasa, Quraish Shihab memaparkan bahwa kata Wasath pada mulanya berarti segala yang baik sesuai objeknya. Orang bijak berkata "Khair al-umûr al-wasth" sebaik-baik segala sesuatu adalah yang dipertengahan. Dengan kata lain yang baik berada pada posisi antara dua ekstrem. Keberanian adalah pertengahan antara sifat ceroboh dan takut. Kedermawanan adalah pertengahan antara sikap boros dan kikir. Selanjutnya, yang menghadapi dua pihak berseteru dituntut untuk menjadi wasith (wasit) yakni berada pada posisi tengah dalam arti berlaku adil, dan dari sini lahir lagi makna ketiga bagi wasath yaitu adil. Yang terbaik, tengah dan adil itulah tiga makna popular dari kata wasath. ${ }^{41}$

Sedangkan kata syuhadầ adalah bentuk jamak dari kata syâhid. Kata ini terambil dari kata syâhida. Sedangkan kata yang terangkai dari huruf-huruf Shin-ha-dal tidak keluar maknanya dari "kehadiran/ keberadaan, pengetahuan serta pemberitahuan. Patron kata syâhid dapat berarti objek dan dapat juga berarti subjek, sehingga syâhid dapat berarti yang disaksisan atau yang menyaksikan. Ini berarti syâhid adalah yang disaksikan oleh pihak lain atau yang dijadikan saksi dalam arti teladan, dan dalam saat yang sama ia pun menyaksikan kebenaran melalui keteladanannya dan atau menyaksikan pula ganjaran Ilahi yang dijanjikan bagi mereka. Nabi Muhammad adalah syâhid dan umatnya adalah syuhadâa' dalam salah satu bahkan kedua makna di atas.

Umat Islam menjadi saksi, sekaligus disaksikan, guna menjadi teladan bagi umat yang lain, dan dalam saat yang sama mereka menjadikan Nabi Muhammad saw. sebagai patron yang mereka teladani sekaligus saksi pembenaran bagi semua aktivitasnya. Ini dapat terjadi karena umat Islam adalah ummatan Wasathan dan Nabi Muhammad adalah tokoh wasat\} iyyah itu. ${ }^{42}$

Sedangkan ayat Al-Qur'an yang menurut para peneliti merupakan satu-satunya ayat yang secara eksplisit menjelaskan konsep wasathiyyah, ditafsirkan oleh Quraish Shihab sebagai berikut:

"Dan demikian pula Kami telah menjadikan kamu wahai umat Islam ummatan

Wasathan/umat pertengahan moderat dan teladan, sehingga dengan demikian keberadaan kamu dalam posisi pertengahan itu sesuai dengan posisi ka'bah yang berada di pertengahan pula. ${ }^{43}$

\footnotetext{
40 Hanafi, Berguru Kepada Sang Guru, h. 148.

41 M. Quraish Shihab, Membumikan Al-Quran 2, h.92.

42 Quraish Shihab, Membumikan Al-Qur'an 2, h. 93.

43 Quraish Shihab, Tafsir Al-Mishbah, vol. 1, h. 325.
}

86 | Al-Fanar: Jurnal Ilmu Al-Qur'an dan Tafsir 
Quraish Shihab berpendapat bahwa karakter wasathiyyah akan mengantar dan mengarahkan manusia kepada karakter dan perilaku adil dan proporsional dalam setiap hal. Selain itu ia pun mendefinisikan konsepsi wasathiyyah berdasarkan beberapa paradigma yang berbeda, tetapi kesemuanya saling menyempurnakan secara substansial. Diantara hal yang sangat penting adalah: pertama, posisi pertengahan menjadikan manusia tidak memihak ke kiri dan ke kanan, hal mana mengantar manusia berlaku adil. Posisi pertengahan menjadikan seseorang dapat dilihat siapapun dalam penjuru yang berbeda, dan ketika itu ia dapat menjadi teladan bagi semua pihak. Posisi itu juga menjadikannya dapat menyaksikan siapa pun dan di mana pun. Allah menjadikan umat Islam pada posis pertengahan agar umat Islam menjadi saksi atas perbuatan manusia yakni umat yang lain. Namun, hal ini tidak dapat dilakukan kecuali jika kalian menjadikan Rasul saw. Syâhid, yakni saksi yang menyaksikan kebenaran sikap dan perbuatan dan beliau pun disaksikan, yakni dijadikan teladan dalam segala tingkah laku. Itu lebih kurang yang dimaksud oleh lanjutan agar Rasul Muhammad menjadi saksi atas perbuatan umatnya. Kedua, ada juga yang memahami ummatan Wasathan dalam arti pertengahan dalam pandangan tentang Tuhan dan dunia. Tidak mengingkari wujud Tuhan tetapi tidak juga menganut paham politeisme (banyak Tuhan). Pandangan Islam adalah Tuhan Maha Wujud dan Dia Yang Maha Esa. Pertengahan juga adalah pandangan umat Islam tentang kehidupan dunia ini. Tidak mengingkari dan menilainya maya, tetapi tidak juga berpandangan bahwa hidup duniawi adalah segalanya. Pandangan Islam tentang hidup adalah disamping ada dunia ada juga akhirat, keberhasilan di akhirat ditentukan oleh iman dan amal shaleh di dunia. Manusia tidak boleh tenggelam dalam materialisme tidak juga membumbung tinggi dalam spiritualisme. Ketika pandangan mengarah ke langit kaki harus tetap berpijak di bumi. Islam mengajar umatnya agar meraih materi duniawi tetapi dengan nilai-nilai samawi. ${ }^{44}$

Quraish Shihab mendefinisikannya berdasarkan tiga prinsip mendasar dari moderatisme Islam (wasathiyyah) yaitu: pertama, wasathiyyah dalam memandang Tuhan dan dunia. Dengan tidak mengingkari wujud Tuhan tetapi tidak juga menganut paham politeisme (banyak Tuhan). Posisi pertengahan menjadikan umat Islam mampu memadukan rohani dan jasmani, material dan spiritual dalam segala sikap dan aktivitas. Kedua, posisi pertengahan menjadikan manusia tidak memihak ke kiri dan ke kanan, hal mana mengantar manusia berlaku adil. Dapat berinteraksi, berdialog, dan terbuka dengan semua pihak. Ketiga, posisi pertengahan menjadikan umat Islam/seorang muslim dilihat oleh siapapun dalam penjuru yang berbeda dan menjadi teladan bagi semua pihak. Di sisi lain kedudukan Nabi Muhammad saw. yang dijadikan saksi dan teladan bagi umat Islam menjadikan umat Islam untuk meneladani Nabi Muhammad saw. dalam nilai-nilai yang beliau ajarkan/terapkan.

Quraish Shihab melihat bahwa dalam moderasi (wasathiyyah) terdapat pilar-pilar penting yakni; Pertama, Pilar keadilan, pilar ini sangat utama, beberapa makna keadilan yang dipaparkan adalah: pertama, adil dalam arti "sama" yakni persamaan dalam hak. Seseorang yang berjalan lurus dan sikapnya selalu menggunakan ukuran yang sama, bukan ukuran ganda. Persamaan itulah yang menjadikan seseorang yang adil tidak berpihak kepada salah seorang yang berselisih. Adil juga berarti penempatan sesuatu pada tempat yang semestinya. Ini mengantar pada persamaan, walau dalam ukuran kuantitas boleh jadi tidak sama. Adil adalah memberikan kepada pemilik hak-haknya melalui jalan yang terdekat. Ini bukan menuntut seseorang memberikan haknya kepada pihak lain tanpa

44 Quraish Shihab, Tafsir Al-Mishbah, vol. 1, h. 325. 
menunda-nunda. Adil juga berarti moderasi 'tidak mengurangi tidak juga melebihkan”. ${ }^{45}$

Kedua, Pilar Keseimbangan. Menurut Quraish Shihab Keseimbangan ditemukan pada suatu kelompok yang di dalamnya terdapat beragam bagian yang menuju satu tujuan tertentu, selama syarat dan kadar tertentu terpenuhi oleh setiap bagian. Dengan terhimpunnya syarat ini, kelompok itu dapat bertahan dan berjalan memenuhi tujuan kehadirannya. Keseimbangan tidak mengharuskan persamaan kadar dan syarat bagi semua bagian unit agar seimbang. Bisa saja satu bagian berukuran kecil atau besar, sedangkan kecil dan besarnya ditentukan oleh fungsi yang diharapkan darinya. ${ }^{46}$

Dalam penafsiran Quraish Shihab, keseimbangan adalah menjadi prinsip yang pokok dalam wasathiyyah. Karena tanpa adanya keseimbangan tak dapat terwujud keadilan. Keseimbangan dalam penciptaan misalnya, Allah menciptakan segala sesuatu menurut ukurannya, sesuai dengan kuantitasnya dan sesuai kebutuhan makhluk hidup. Allah juga mengatur sistem alam raya sehingga masing-masing beredar secara seimbang sesuai kadar sehingga langit dan benda-benda angkasa tidak saling bertabrakan. ${ }^{47}$

Ketiga, Pilar Toleransi. Quraish Shihab memaparkan bahwa toleransi adalah batas ukur untuk penambahan atau pengurangan yang masih bisa diterima. Toleransi adalah penyimpangan yang tadinya harus dilakukan menjadi tidak dilakukan, singkatnya adalah penyimpangan yang dapat dibenarkan. ${ }^{48}$ Keniscayaan perbedaan dan keharusan persatuan itulah yang mengantarkan manusia harus bertoleransi. Kedamaian, kemaslahatan dan kemajuan tidak dapat dapat dicapai bila tanpa adanya toleransi.

Diantara toleransi yang sangat awal dalam ajaran Islam adalah tidak adanya paksaan untuk seseorang memeluk agama Islam. Allah menghendaki agar setiap orang merasakan kedamaian. Agama-Nya dinamai Islam yakni damai. Kedamaian tidak dapat diraih kalau jiwa tidak damai. Paksaan menyebabkan jiwa tidak damai, karena itu tidak ada paksaan dalam menganut keyakinan agama Islam. Tidak ada paksaan dalam menganut agama karena telah jalan yang lurus. Itu sebabnya orang gila dan orang yang belum dewasa atau tidak mengetahui tuntunan agama tidak berdosa jika melanggar atau menganutnya, karena jalan jelas itu belum diketahuinya. Namun, juga perlu diingat bahwa orang yang memiliki potensi mengetahui tetapi tidak mau mencari pengetahuan, maka itu juga tidak benar, karena dia akan dituntut karena menyia-nyiakan potensinya. ${ }^{49}$

Tidak ada paksaan dalam menganut agama. Artinya, jika seseorang telah memilih satu akidah, misalkan agama Islam, maka otomatis dia terikat dengan tuntunan-tuntunannya, dia berkewajiban melaksanakan perintah-perintahnya. Dia terancam sanksi bila melanggar ketetapannya. Dia tidak boleh berkata, "Allah telah memberi saya kebebasan untuk shalat atau tidak, berzina atau nikah", karena bila dia telah menerima akidahnya, maka dia harus melaksanakan tuntunannya. ${ }^{50}$

Pada konteks Indonesia tentu saja perlu adanya penerapan moderatisme Islam yang lebih luas terutama bagi umat non-muslim. Melakukan aneka kebajikan bagi non-muslim dibenarkan selama tidak membawa dampak negatif bagi umat Islam kecuali bagi mereka yang jelas-jelas memerangi dan peperangan yang disebabkan kepentingan duniawi yang

45 Quraish Shihab, Tafsir Al-Mishbah, an-Nahl [16]: 19.

46 Quraish Shihab, Membumikan Al-Qur'an, h.115.

47 Quraish Shihab, Tafsir Al-Mishbah, vol. 13, h. 284.

48 Quraish Shihab, Tafsir Al-Mishbah, vol. 1, h. 551.

49 Quraish Shihab, Tafsir Al-Mishbah, vol. 1, h. 551-552.

50 Quraish Shihab, Tafsir Al-Mishbah, vol. 1, h. 551.

88 | Al-Fanar: Jurnal Ilmu Al-Qur'an dan Tafsir 
tidak ada hubungannya dengan agama, dan tidak termasuk pula siapapun yang secara faktual memerangi umat Islam. Adapun jika mereka bersikap damai, Islam tidak berminat untuk melakukan permusuhan dan tidak juga berusaha melakukannya. ${ }^{51}$

\section{PENUTUP}

Karakter moderasi Islam menurut Quraish Shihab menggambarkan sifat moderat yang dimiliki oleh umat Islam, yakni tidak condong kearah berlebih-lebihan (ifrâth) ataupun meremehkan (tafrîth) dalam berbagai permasalahan yang terkait dengan agama atau dunia. Bukan termasuk kelompok mereka yang ekstrem dalam beragama (arbâb alghuluw fî ad-dîn al-mufrithîn), dan bukan pula termasuk yang menganulir ketentuanketentuan agama (arbab at-ta'thil al-mufarrithîn). Bukan pula orang-orang materialis seperti Yahudi dan Mushrikin bukan pula orang-orang rohaniawan seperti Nashara. Namun, mereka menggabungkan dua hak: hak jasad dan hak roh, serta tidak melalaikan salah satu sisi atas yang lainnya. Hal ini selaras dengan fitrah manusia yang terdiri dari jasad dan roh. Begitu juga dalam memandang sesuatu mereka berfikir secara objektif, komprehensif, dan konsisten.

\section{DAFTAR PUSTAKA}

Abadi, Majd ad-Dîn al-Fairuz, al-Qâmûs al-Muhîth, t.tp: Mu'assasah ar-Risalah, t.th

Abdullah, Abdurahman M., (Baadiyow), The Islah Movement:Islamic Moderation in War-torn Somalia, Mogadishu: t.p., 2008

Abi Syaibah, Abu Bakr Abdullah bin Ibn, Mushannaf Ibn Abî-Syaibah, t.tp: Dar al-Qiblah dan Dar as-Salafiyah al-Hindiah al-Qadîmah, t.th.

Al-Ashfahani, Raghib, Mufradât Alfâzh Al-Qur'an, Damaskus: Dâr al-Qalam, t.th.

Al-Baihaqi, Ahmad bin al-Husain Abu Bakr, Shu'ab al-Iman, Riyadh: Maktabah ar-Rushd, $1423 / 2003$.

Echols, John M., dan Hasan Shadily, An English-Indonesiam Dictionary, Jakarta: PT. Gramedia Pustaka Utama, 2005.

Al- Fayumi, Ahmad bin Muhammad al-Muqri, al-Mishbâh al al-Munîr fî̀ Garîb asy-Syarh alKabî, Beirut: al Maktabah al Ilmiah, t.th.

Federspiel, Howard M., Kajian Al-Qur'an Indonesia: Dari Mahmud Yunus Hingga Quraish Shihab, terj. Tajul Arifin, Bandung: Mizan, 1996

Hanafi, Muklis M., "Peran Al-Azhar dalam Penguatan Moderasi Islam” Paper pada Seminar Ikatan Alumni Al-Azhar Internasional (IAAI) cabang Indonesia bekerja sama dengan Kedutaan Besar Mesir di Jakarta dan Fakultas Dirasat Islamiyah UIN Syarif Hidayatullah Jakarta. Moderasi Islam, Ciputat: Ikatan Alumni Al-Azhar dan Pusat Studi Al-Qur'an, t.th.

"Konsep al-Wasathiyyah dalam Islam", Harmoni: Jurnal Multikultural dan Multireligius, Vol. VIII, (Oktober-Desember, 2009).

Harras, Muhammad Khalil, Syarh al-Aqîdah al-Wasathiyyah, t.tp: ar-Ri'âsah al-Ammah li Idârat al-Buhûtts al-'Ilmiyyah wa al-Iftâ' wa ad-Da'wah wa al-Irsyad, t.th.

Ibn Faris, Abu al Husain Ahmad, Mujam Maqâyis al-Lughagh, t.tp: Dar al-Fikr, 1399/1979

51 Quraish Shihab, Tafsir Al-Mishbah, vol. 13, h. 598-599. 


\section{MODERATISME ISLAM DALAM KONTEKS KEINDONESIAAN}

(Studi Penafsiran Islam Moderat M. Quraish Shihab)

Ibn Manzhur, Lisân al-Arab, Beirut: Dâr ash-Shadir, t.th

Ismail, Achmad Satori, et.al., Islam Moderat: Menebar Islam Rahmatan lil Alamin, Jakarta: Pustaka Ikadi, 2007.

Johnson, “Toleransi Dan Moderasi Inti Ajaran Islam”, www.tribunews.com, diakses 1 April 2013.

Muammar, Khalif, Atas Nama Kebenaran, Tanggapan Kritis terhadap Wacana Islam Liberal, Kuala lumpur: Akademi Kajian Ketamadunan, 2006.

Mustafa, M. Quraish Shihab Membumikan Kalam di Indonesia, Yogyakarta: Pustaka Pelajar, 2010.

An-Najjar, Muhammad Ali, Mujjam Alfâzh Al-Qur'an al-Karîm, Kairo: Majma' al-Lughagh al-'Arabiyyah, 1996

Al-Qarad\}awi, Yusuf, al-Khashâish al-Âmmah li al-Islâm, Beirut: Mu'assasah ar-Risalah, $1404 / 1983$

Ar-Râzi, Muhammad Abd al-Qadîr, Mukhtâr ash-Shihhâhah, Beirut: Makatabah Lubanan Naasyirun, 1415/1995

Ash-Shalabi, Ali Muhammad Muhammad, al-Wasathiyyah fì Al-Qur'an, Kairo: Maktabat at Tâbỉin, 1422/2001

Al-Shaukani Muhammad Ali, Fath al-Qadîr: al-Jâmi' Bayna Fannayi ar-Riwâyah wa adDirâyah min 'Ilm at-Tafsîr, Riyadh: Maktabah ar-Rushd, 1428 H/2007 M

Shihab, M. Quraish, Tafsir Al-Mishbah, Ciputat: Lentera Hati, 2000 - Membumikan Al-Quran: Fungsi dan Peran Wahyu dalam Kehidupan Masyarakat, Bandung: Mizan, 2007

Asy-Syihristâni, Abû al-Fath Muhammad bin Abd al-Karîm, al-Milâl wa an-Nihhâl, Syiria: Mu'assah Al-Halabi, t.th.

Subhan, Arief, Tafsir Yang Membumi, Jakarta: Majalah Tsafaqah, 2003.

Tim Penyusun Kamus Pusat Bahasa, Kamus Besar Bahasa Indonesia, Jakarta: Balai Pustaka, 2005.

Az-Zuhailî, Muhammad, Indahnya Islam: Di tengah Tarikan Kaum Ekstrim dan Liberal, terj. Kuwais dan Ahmad Yunus Naidi, Jakarta: Akbar Media Eka Sarana, 1492/2008 